DOI : https://doi.org/10.33330/jurteksi.v5i1.273

Available online at http://jurnal.stmikroyal.ac.id/index.php/jurteksi

\title{
DETEKSI GERAKAN KEPALA DAN KEDIPAN MATA DENGAN HAAR CASCADE CLASSIFIER CONTOUR DAN MORFOLOGI DALAM PENGOPERASIAN KOMPUTER UNTUK KAUM DIFABLE
}

\author{
I Komang Setia Buana ${ }^{1}$, Ni Made Dwi Kansa Putri ${ }^{2}$ \\ ${ }^{1,2}$ STMIK STIKOM Bali \\ J1. Raya Puputan No.86 Renon, Denpsar Bali, (0361)244445 \\ e-mai: ${ }^{1}$ buana@stikom-bali.ac.id, ${ }^{2}$ kansa@ stikom-bali.ac.id
}

\begin{abstract}
Abstrack: Diffable or the word that has defenition is "Different Abled People" the term for disabled people. One example of disabled is people who do not have hands, so to write even have to use their feet. Along with the increasingprogress of computer technology, the role of computer technology has also increased for the benefit of humans. One of them is the field of human and computer interaction ( IMK) or also called Human Computer Interaction ( HCI) . Although computer technology equipment is accurate and reliable, but the interaction model that is carried out is not natural as humans interact with each other, the use of such equipment to operate it requires direct contact between user and the computer. For people who dissabilities who do not have hands, it will be difficult to do so. Computer vision based interaction techniques are candidates for natural interaction techniques. The human head can also be used to replace the function of a mouse that can be used to move the cursor up and down left or right for and to click on the mouse using the blik an eye. Detection using head movements has been widely applied including in the fields of entertainment, education, and security. The camera is a tool used to make head recognition. The camera is used as a sensor to detect head movements. Head motion detection is implemented by using opency phython.
\end{abstract}

Keyword: difabel, head, webcame, opencv python

\begin{abstract}
Abstak: Difabel atau kata yang memiliki definisi "Different Abled People" ini adalah sebutan bagi orang cacat. Salah satu contoh kaum difabel adalah orang yang tidak mempunyai tangan, sehingga untuk menulispun harus menggunakan kaki. Seiring meningkatnya kemajuan teknologi komputer, peranan teknologi komputer juga semakin meningkat yang digunakan untuk kepentingan manusia. salah satunya adalah bidang interaksi manusia dan komputer (IMK), atau sering disebut Human Computer Interaction (HCI). Keyboard, mouse, dan joystick merupakan salah satu perangkat keras yang sering digunakan untuk interaksi antara manusia dan komputer yang bersifat mekanis. Meskipun peralatan-peralatan tersebut akurat dan handal (reliable), tetapi model interaksi yang dilakukan tidak bersifat alami sebagaimana manusia berinteraksi dengan sesamanya, penggunaan peralatan-peralatan tersebut untuk mengoperasikannya membutuhkan adanya kontak langsung antara user dengan komputer. Untuk kaum difabel yang tidak mempunyai tangan, akan susah melakukan hal tersebut. Teknik interaksi berbasis visi komputer menjadi kandidat teknik interaksi yang bersifat alami. kepala manusia bisa juga digunakan untuk menggantikan fungsi mouse yang bisa digunakan untuk menggerakan cursor keatas kebawah kekiri maupun kekanan dan untuk melakukan klik pada mouse menggunakan kedipan mata. Pendeteksian menggunakan gerakan kepala telah diaplikasikan secara luas diantaranya pada bidang hiburan,
\end{abstract}


pendidikan serta keamanan. Kamera (webcam) merupakan alat yang digunakan untuk melakukan pengenalan kepala. Kamera ini digunakan sebagai sensor untuk mendeteksi pergerakan kepala. Pendeteksian gerakan kepala diimplementasikan dengan menggunakan opencv python.

Kata Kunci : difabel, kepala, webcame, opencv python

\section{PENDAHULUAN}

Difabel atau kata yang memiliki definisi "Different Abled People" ini adalah sebutan bagi orang cacat. Kata ini sengaja dibuat oleh lembaga yang mengurus orang orang cacat dengan tujuan untuk memperhalus kata - kata atau sebutan bagi seluruh penyandang cacat yang kemudian mulai ditetapkan pada masyarakat luas pada tahun 1999 untuk menggunakan kata ini sebagai pengganti dari kata cacat. Salah satu contoh kaum difabel adalah orang yang tidak mempunyai tangan, sehingga untuk menulispun harus menggunakan kaki.

\section{Seiring meningkatnya}

kemajuan teknologi komputer, peranan teknologi komputer juga semakin meningkat yang digunakan untuk kepentingan manusia. salah satunya adalah bidang interaksi manusia dan komputer (IMK), atau sering disebut Human Computer Interaction (HCI). Keyboard, mouse, dan joystick merupakan salah satu perangkat keras yang sering digunakan untuk interaksi antara manusia dan komputer yang bersifat mekanis. Meskipun peralatanperalatan tersebut akurat dan handal (reliable), tetapi model interaksi yang dilakukan tidak bersifat alami sebagaimana manusia berinteraksi dengan sesamanya, penggunaan peralatan-peralatan tersebut untuk meng-operasikannya membutuhkan adanya kontak langsung antara user dengan komputer. Untuk kaum difabel yang tidak mempunyai tangan, akan susah melakukan hal tersebut. Teknik interaksi berbasis visi komputer menjadi kandidat teknik interaksi yang bersifat alami. Teknik ini tidak membutuhkan kontak langsung pengguna dengan peralatan input, melainkan komputer menangkap gerakan pengguna melalui kamera video dan menginterpretasikannya. Input secara visual dapat memberikan kemampuan penginderaan pada komputer sebagaimana manusia melakukan penginderaan menggunakan mata. Interaksi antar manusia secara alami tidak membutuhkan mouse atau keyboard, melainkan diantaranya menggunakan kepala dan mata untuk mendapatkan informasi dari lingkungan. kepala manusia bisa juga digunakan untuk menggantikan fungsi mouse yang bisa digunakan untuk menggerakan cursor keatas kebawah kekiri maupun kekanan dan untuk melakukan klik pada mouse menggunakan kedipan mata[1].

Sesuai dengan penelitian sebelumnya yang dilakukan oleh I Komang Setia Buana untuk kedipan mata menggunakan library 
DOI : https://doi.org/10.33330/jurteksi.v5i1.273

Available online at http://jurnal.stmikroyal.ac.id/index.php/jurteksi

extract.find_blinks_using_edge,

Pendeteksian kedipan mata harus dikondisi yang terang dan jarak maksimal $50 \quad \mathrm{CM}$ untuk hasil maksimal. Sedangkan jarak tersebut termasuk dekat dengan komputer sehingga dibutuhkan metode yang lebih akurat. Didalam penelitian ini metode untuk mendeteksi kedipan menggunakan Haar Cascade Classifier Dan Contour.

\section{Python}

Python adalah bahasa pemrograman interpretatif multiguna dengan filosofi perancangan yang berfokus pada tingkat keterbacaan kode. Python diklaim sebagai bahasa yang menggabungkan kapabilitas, kemampuan, dengan sintaksis kode yang sangat jelas, dan dilengkapi dengan fungsionalitas pustaka standar yang besar serta komprehensif. Python juga didukung oleh komunitas yang besar. Python mendukung multi paradigma pemrograman, utamanya; namun tidak dibatasi; pada pemrograman berorientasi objek, pemrograman imperatif, dan pemrograman fungsional [5]. Salah satu fitur yang tersedia pada python adalah sebagai bahasa pemrograman dinamis yang dilengkapi dengan manajemen memori otomatis. Seperti halnya pada bahasa pemrograman dinamis lainnya, python umumnya digunakan sebagai bahasa skrip meski pada praktiknya penggunaan bahasa ini lebih luas mencakup konteks pemanfaatan yang umumnya tidak dilakukan dengan menggunakan bahasa skrip. Python dapat digunakan untuk berbagai keperluan pengembangan perangkat lunak dan dapat berjalan di berbagai platform sistem operasi. Python didistribusikan dengan beberapa lisensi yang berbeda dari beberapa versi. Lihat sejarahnya di Python Copyright. Namun pada prinsipnya Python dapat diperoleh dan dipergunakan secara bebas, bahkan untuk kepentingan komersial. Lisensi Python tidak bertentangan baik menurut definisi Open Source maupun General Public License (GPL). Python dikembangkan oleh Guido van Rossum pada tahun 1990 di Stichting Mathematisch Centrum (CWI), Amsterdam sebagai kelanjutan dari bahasa pemrograman ABC. Versi terakhir yang dikeluarkan CWI adalah 1.2. Tahun 1995, Guido pindah ke CNRI di Virginia Amerika sambil terus melanjutkan pengembangan Python. Versi terakhir yang dikeluarkan adalah 1.6. Tahun 2000, Guido dan para pengembang inti Python pindah ke BeOpen.com yang merupakan sebuah perusahaan komersial dan membentuk BeOpen PythonLabs. Python 2.0 dikeluarkan oleh BeOpen. Setelah mengeluarkan Python 2.0, Guido dan beberapa anggota tim PythonLabs pindah ke DigitalCreations. Saat ini pengembangan Python terus dilakukan oleh sekumpulan pemrogram yang dikoordinir Guido dan Python Software Foundation. Python Software Foundation adalah sebuah organisasi non-profit yang dibentuk sebagai pemegang hak cipta intelektual Python sejak versi 2.1 dan dengan demikian mencegah Python dimiliki oleh perusahaan komersial. Saat ini distribusi Python sudah mencapai versi 
DOI : https://doi.org/10.33330/jurteksi.v5i1.273

Available online at http://jurnal.stmikroyal.ac.id/index.php/jurteksi

2.7.4 dan versi 3.6.3 Nama Python dipilih oleh Guido sebagai nama bahasa ciptaannya karena kecintaan Guido pada acara televisi Monty Python's Flying Circus. Oleh karena itu seringkali ungkapan-ungkapan khas dari acara tersebut seringkali muncul dalam korespondensi antar pengguna Python.

\section{Ektraksi Fitur}

Metode untuk perpindahan gambar yang paling mudah untuk dipahami adalah pendekatan berbasis fitur. Metode ini menemukan fitur (misalnya, tepi citra, sudut, dan struktur lainnya) dan penelusuran ini dilakukan ketika gambar bergerak dari frame ke frame. Tindakan ekstraksi fitur, jika dilakukan dengan baik, akan mengurangi jumlah informasi untuk diproses (dan mengurangi beban kerja) [2].Untuk mengenali atau mengklasifikasikan obyek dalam gambar, seseorang harus terlebih dahulu ekstrak beberapa fitur keluar gambar, dan kemudian menggunakan fitur ini di dalam pola untuk memperoleh classifier final kelas. Fitur ekstraksi (atau deteksi) bertujuan untuk mencari daerah fitur yang signifikan pada gambar tergantung pada karakteristik intrinsik mereka dan aplikasi. Wilayah tersebut dapat didefinisikan dalam lingkungan global atau lokal dan dibedakan oleh bentuk, tekstur, ukuran, intensitas, sifat statistik, dan sebagainya. Metode ekstraksi fitur Lokal dibagi menjadi intensitas sesuai dan struktur berbasis. Intensitas metode berbasis analisis pola intensitas lokal untuk menemukan daerah yang memenuhi keunikan yang diinginkan atau stabilitas kriteria. Struktur berbasis metodemendeteksi struktur gambar seperti tepi, garis, sudut, lingkaran, elips, dan sebagainya. Fitur ekstraksi cenderung untuk mengidentifikasi ciri-ciri yang dapat membentuk representasi yang baik dari objek, sehingga dapat membedakan dikategori objek dengan variasi toleransi.

\section{Segmentasi}

Segmentasi adalah proses membagi citra digital menjadi beberapa daerah. Segmentasi menunjukkan objek dan batas-batas dalam gambar. Setiap piksel di wilayah ini memiliki beberapa karakteristik yang sama seperti warna, intensitas, dll. Beberapa metode untuk segmentasi gambar yang dijelaskan di bawah ini [9].

a) Segmentasi Berbasis Histogram

Salah satu cara sederhana untuk melakukan segmentasi yaitu menggunakan histogram. Histogram dihitung untuk semua piksel gambar. Puncak di histogram dibuat oleh nilai intensitas yang dibuat setelah menerapkan ambang batas dan clustering. Nilai piksel digunakan untuk menemukan daerah dalam gambar. Berdasarkan nilai-nilai histogram dan ambang, kita dapat mengklasifikasikan nilai intensitas rendah sebagai objek dan nilai-nilai tinggi gambar sebagai latar belakang.

b) Perbedaan Frame

Perbedaan frame digunakan untuk menghitung antara 2 frame di setiap piksel posisi dan menyimpan nilai perbedaan tersebut. Hal ini digunakan untuk memvisualisasikan benda 
DOI : https://doi.org/10.33330/jurteksi.v5i1.273

Available online at http://jurnal.stmikroyal.ac.id/index.php/jurteksi

bergerak di urutan frame.

c) Metode Single Gaussian Background

Metode ini digunakan untuk melakukan pemisahkan latar belakang dan objek di latar depan. Itu merupakan metode pemisahan statis. Dalam ini serangkaian bingkai (frame sebelumnya) yang diambil dan perhitungan dilakukan untuk pemisahan. Pemisahan dilakukan dengan menghitung rata-rata $\sigma$ dan varians $\mu$ di setiap posisi piksel.

\section{Proses Morfologi}

Citra biner dapat mengandung banyak ketidak sempurnaan. Secara khusus, daerah biner yang dihasilkan oleh thresholding terdistorsi oleh noise dan tekstur. Pengolahan citra Morfologi bertujuan untuk menghapus ketidak sempurnaan tersebut. Operasi dasar dari morfologi ada dua yaitu dilasi dan erosi.

\section{Dilasi}

Dilasi adalah suatu proses menambahkan piksel pada batasan dari objek dalam suatu gambar sehingga nantinya apabila dilakukan operasi ini maka gambar hasilnya lebih besar ukurannya dibandingkan dengan gambar aslinya. Dilasi ini sangat berguna ketika diterapkan dalam obyek-obyek yang terputus dikarenakan hasil pengambilan citra yang terganggu oleh noise, kerusakan obyek fisik yang dijadikan citra digital, atau disebabkan resolusi yang jelek, contohnya teks pada kertas yang sudah agak rusak sehingga bentuk hurufnya terputus, dan sebagainya.

2. Erosi
Erosi sendiri adalah kebalikan dari dilasi. Proses ini akan membuat ukuran sebuah citra menjadi lebih kecil. Berbeda dengan dilasi, apabila erosi dilakukan maka yang dikerjakan adalah memindahkan piksel pada batasan-batasan objek yang akan di erosi. Jumlah dari piksel yang ditambah atau dihilangkan bergantung pada ukuran dan bentuk dari structuring element yang digunakan untuk memproses gambar tersebut.

\section{Haar Cascade Classifier}

Haar Cascade Classifier merupakan rectangular feature, yang memberikan indikasi secara sepesifik pada sebuah gambar atau image. Metode ini merupakan metode yang menggunakan statistikal model. Pendekatan untuk mendeteksi objek dalam gambar menggabungkan empat kunci utama yaitu Haar like feature, Integral Image, Adaboost learning dan cascade classifier[3].

\section{METODE}

Perancangan sistem dalam penelitian ini dibagi menjadi dua kegiatan yaitu pengambilan data dan pengolahan data. Pengambilan data adalah hal yang dilakukan pertama kali, setelah itu data yang sudah diambil diolah menggunakan aplikasi. Pengambilan Data

Data gerakan kepala didapat dari webcame. Data tersebut akan diolah untuk proses berikutnya Pengolahan Data

Dalam melakukan pengolahan data dalam penelitian ini menggunakan teknik pengolahan citra. Teknik 
DOI : https://doi.org/10.33330/jurteksi.v5i1.273

Available online at http://jurnal.stmikroyal.ac.id/index.php/jurteksi

pengolahan citra terdiri dari segmentasi, ektraksi fitur, dan proses morfologi pada citra.

Alur kerja sistem ini seperti terlihat dibawah:

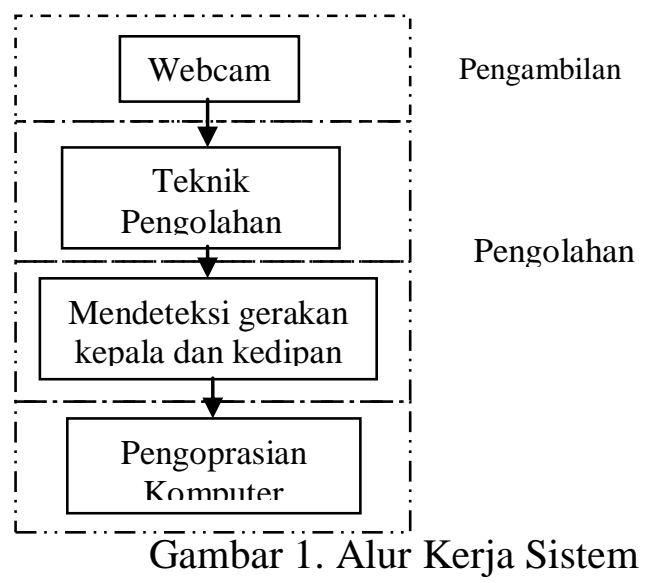

Tahap pengolahan data untuk mendapatkan hasil :

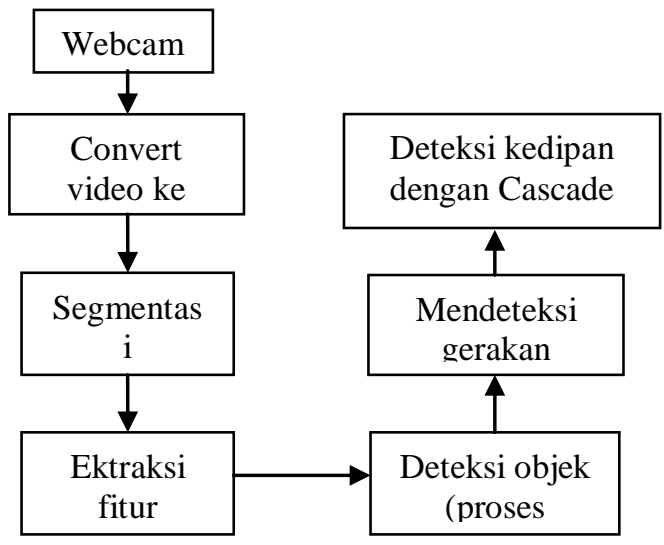

Gambar 3.2 Pengolahan data

\section{HASIL DAN PEMBAHASAN}

\section{Implementasi Sistem}

Hasil eksperimen dilakukan dengan menggunakan teknologi computer vision. Perangkat lunak yang digunakan dalam penelitian ini :
1. IDLE (Python GUI)
2. JDK 1.7

3. OpenCV 2.4.0

4. $\quad$ Python 2.7

Untuk mengetahui performa dari sistem ini, maka dibutuhkan pengujian dengan cara pengambilan data. Pengujian dilakukan dengan menggunakan data berupa hasil dari webcame. Sedangkan mesin pengolah yang digunakan adalah sebuah komputer dengan spesifikasi :

1. Processor Intel Core i3 CPU @ $1,8 \mathrm{GHz}$

2. Memory $4 \mathrm{~GB}$

3. VGA Card NVIDIA GEFORCE $720 \mathrm{M}$

\section{Tahap Segmentasi}

Pada tahap ini akan dilakukan proses segmentasi yaitu memisahkan objek dan latar belakang dengan menggunakan perbedaan frame. Tahap awal dari proses segmentasi adalah menganggap frame pertama sebagai background frame, kemudian mencari nilai threshold, untuk mencari nilai threshold dilakukan dengan membuat citra histogram. setelah didapatkan nilai threshold lakukan pengecekan dengan frame berikutnya, proses tersebut dilakukan berulang kali sampai frame terakhir. Hasil dri proses segmentasi :

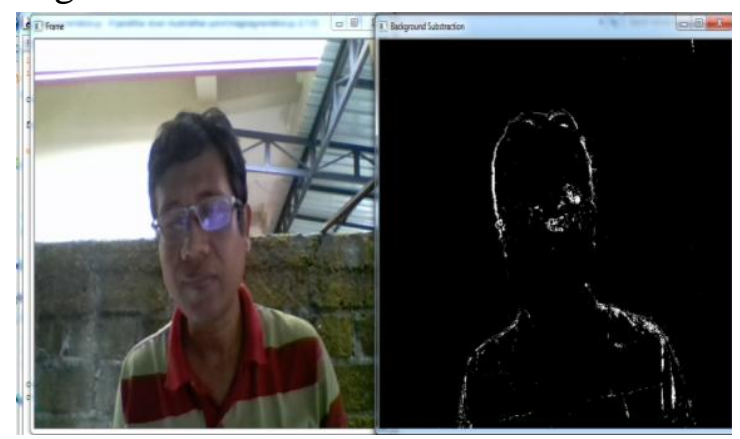

Gambar 2. Hasil Dari Proses Segmentasi 
DOI : https://doi.org/10.33330/jurteksi.v5i1.273

Available online at http://jurnal.stmikroyal.ac.id/index.php/jurteksi

Dari hasil segmentasi, akan terdapat daerah - daerah yang dianggap sebagai gangguan. Biasanya daerah gangguan tersebut berukuran kecil. Untuk meng-hilangkannya dilakukan proses smoothing menggunakan gaussian smoothing. Gaussian smoothing atau sering disebut gaussian blur tersebut akan memblurkan suatu daerah yang tidak diperlukan, caranya dengan melihat daerah disekitar dari daerah tersebut, daerah mana yang lebih dominan kemudian daerah gangguan tersebut akan diblurkan sehingga daerah tersebut menyerupai daerah disekitarnya.

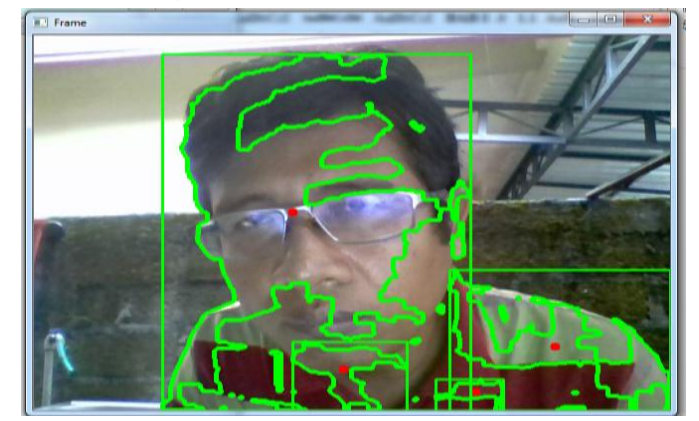

Gambar 3. Hasil dari proses morfologi

\section{Tahap Deteksi Kepala Dan Mata}

Dalam melakukan pendeteksian objek bergerak ektraksi fitur memainkan peran yang sangat penting, dalam penelitian ini menerapkan algoritma canny. Fungsi mendapatkan tepian objek adalah untuk mengetahui luasannya sehingga memudahkan dalam proses klasifikasi. Langkah-langkah dari proses deteksi tepi canny adalah pertama kali dilakukan penghalusan (smoothing) citra untuk menghilangkan noise dengan melakukan Gausian Filter. Setelah itu dilakukan pencarian gradient citra, untuk melihat daerahdaerah yang memiliki turunan spasial yang tinggi. Dari proses tersebut akan terlihat mana daerah yang memiliki perbedaan warna. Kemudian dilakukan Non-maximum Suppression, yaitu meng-hilangkan nilai-nilai yang tidak maksimum dan menghilangkan setiap piksel yang tidak maksimum. Setelah itu dilakukan proses hysteresis dengan menggunakan dua nilai threshold.

Threshold Bila magnitude ada dibawah threshold pertama maka titik tersebut akan diset menjadi nol, jika magnitude berada diatas threshold kedua maka termasuk edge. Bila magnitude berada diantara maka diset menjadi 0 kecuali path dari titik tersebut ke titik yang memiliki magnitude diatas nilai threshold kedua. Hasil dari deteksi tepi canny dan segmentasi yang sudah dilakukan sebelumnya sehingga didapat pendeteksian kepala dan mata.

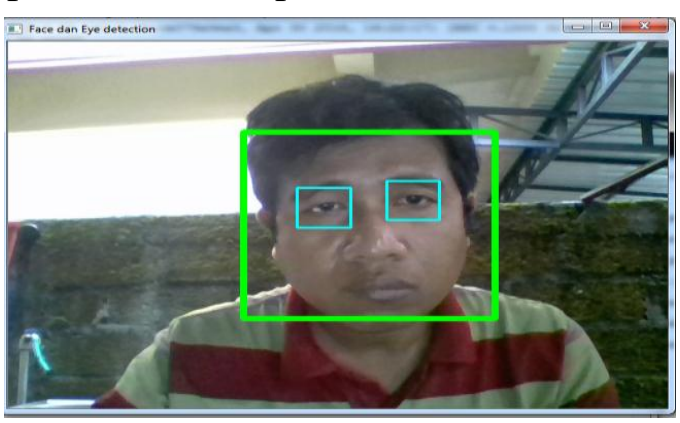

Gambar 4. Proses Deteksi Kepala dan Mata

\section{Menggerakkan Mouse Dan Deteksi Kedipan}

Setelah proses segmentasi dan ekstraksi fitur selesai proses berikutnya adalah deteksi mata dengan haar cascade Classifier. Setelah mata dideteksi dilakukan pencarian contour. 
DOI : https://doi.org/10.33330/jurteksi.v5i1.273

Available online at http://jurnal.stmikroyal.ac.id/index.php/jurteksi

Tahap tahap yang dilakukan untuk mendapatkan contour adalah dengan membuat citra menjadi negativ atau sering disebut negative contour. Setelah dibuat negative contour dilakukan proses thresholding kembali untuk menyempurnaan deteksi mata. Setelah proses thresholding dilakukan proses deteksi kedipan. Kesempurnaan contour mata akan membuat deteksi kedipan mata lebih baik.

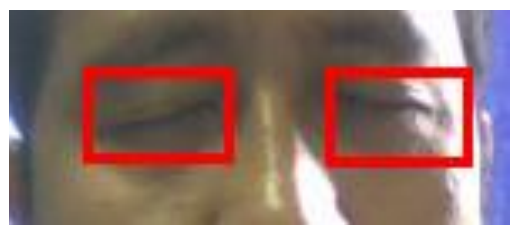

Gambar 5. Proses Deteksi Kedipan

Setekah kedipan terdeteksi warna rectangle berubah mejadi merah dan even click menggunakan library open cv phyton yaitu cv2.setMouseCallback ('frame', mouse).

\section{SIMPULAN}

Kesimpulan yang dapat diambil dari penelitian ini adalah :

a. Aplikasi mendeteksi gerakan kepala dan mata dengan teknik pengolahan citra menggunakan webcame bawaan dari laptop dengan resolusi $1 \mathrm{MP}$

b. Jarak antara kepala dan webcame sangat berpengaruh untuk aplikasi ini, dimana jika kepala terlalu dekat dengan webcame maka pendeteksian tidak akan berhasil dan sebaliknya. Jarak ideal agar terdeteksi sempurna adalah 20 sampai $100 \mathrm{~cm}$.

c. Pendeteksian mata ketika menggunakan kacamata tidak berhasil. Untuk metode yang peneliti gunakan sebaiknya tidak menggunakan kacamata.

\section{DAFTAR PUSTAKA}

[1] Setia Buana, I Komang. "Aplikasi Untuk Pengoprasian Komputer Dengan Mendeteksi Gerakan Menggunakan Opencv Python". Seminar Nasional Teknologi dan Aplikasi Komputer(SINTAK);2018.

[2] Revathi, R; Hemalatha, M. (2012). Certain Approach of Object Tracking using Optical Flow Techniques. International Journal of Computer Applications (0975 - 8887) Volume 53- No.8. September 2012.

[3] RD, K.; Pambudi, W. S.; Tompunu, A. N. Aplikasi Sensor Vision untuk Deteksi MultiFace dan Menghitung Jumlah Orang. Seminar Nasional Teknologi Informasi \& Komunikasi Terapan 2012 (Semantik 2012), Semarang, Juni 2012.

[4] Winarno, Edy. (2011). Aplikasi Deteksi Tepi pada Realtime Video menggunakan Algoritma Canny Detection. Jurnal Teknologi Informasi DINAMIK Volume 16, No.1. Januari 2011.

[5] Budiharto Pemrograman, Widodo. Python Untuk Ilmu Komputer Dan Teknik, Andi Offset (2018). 